\title{
Citizenship in the United States: A Historical Assessment of a Present-Day Contretemps
}

\section{John Allphin Moore, Jr.}

California State Polytechnic University

\begin{abstract}
In late 2015, debate among many US Republican presidential candidates focused on immigration policy, with one candidate who was hostile to America's immigration policy, opining that the $14^{\text {th }}$ Amendment's definition of citizenship may be unconstitutional. This was the view of the GOP candidate who eventually won the Presidency. The question of citizenship, and the linked issue of rights, was contested in the early republic. Much of the quarrel revolved around the issue of slavery. At least three competing notions of citizenship and rights gained traction by the first half of the $19^{\text {th }}$ century: one argued for citizenship and rights only for whites; another urged that "popular sovereignty" should determine rights and citizenship. A third insisted on an inclusive definition of citizenship. By 1868, the $14^{\text {th }}$ Amendment underscored the latter view. But, as current affairs in America show, the bickering persists, often using arguments similar to those found in the early republic's squabbles. This essay explores the debate among the viewpoints articulated during the first half of the $19^{\text {th }}$ century and seeks to draw out counsel for our own time.
\end{abstract}

Keywords: citizenship, immigration, rights, empire, constitutionalism

Presidential politics in America often bring out peculiar assertions, especially in quadrennial primary seasons, as aspirants for the highest office in the land bend to compete for activists' votes. In late 2015, fervid deliberations focused on America's immigration policy and related issues, with at least one candidate provoking cognitive dissonance by opining that the $14^{\text {th }}$ Amendment's definition of citizenship may be unconstitutional. 
The assertion, by Donald Trump, eventual winner of the 2016 presidential campaign, rested within a curious historical context. The $14^{\text {th }}$ Amendment was the middle of the Reconstruction Amendments intended by its Republican framers to alter fundamentally the nature of the American political and social system. Indeed, the three Amendments $\left(13^{\text {th }}, 14^{\text {th }}\right.$, and $\left.15^{\text {th }}\right)$ taken together, established an inclusive notion of American citizenship, ending slavery, nationalizing citizenship and rights, and extending voting privileges to former (male) slaves. Of the three, the $14^{\text {th }}$ Amendment has persistently been the most debated while being discernibly impactful, in both political and juridical sense.

For example, during the 2016 Republican presidential primary campaign, some GOP candidates (Trump among them) - opposed to what was termed "anchor babies," children born within the United States to immigrant non-citizens - advocated ending the $14^{\text {th }}$ Amendment's provision for birthright citizenship. ${ }^{1}$

But the most far-reaching of the $14^{\text {th }}$ Amendment's repercussions have been in the courts. Here are just a few examples among the several controversial legal decisions based on the Amendment (and typically opposed by conservatives):

1) Gitlow v. New York (1925), one of the Supreme Court's earliest decisions to institute the principle, derived from the $14^{\text {th }}$ Amendment, of "incorporation," that is, having the protections of the Bill of Rights be applied to states as well as to the national government.

2) Brown v. Board of Education (1954), in which the Court ruled unanimously that "separate" is inherently "unequal." Thus, public school segregation based on race was found in violation of the 14th Amendment's Equal Protection Clause.

3) Griswold v. Connecticut (1965), which announced a fundamental "right to privacy" that was protected by the 14th Amendment's Due Process Clause. Griswold's "right to privacy" has been applied to many other

1 See Amber Phillips, "Republicans want to change the 14th Amendment. But that often requires war, crisis or death," The Washington Post, August 19, 2015, at <https://www.washingtonpost.com/.../republicans-wantto-change-the-14th-amendment-but-that-often-requires-war-crisis-0r-death/?utm_term=96b151f62f5e >. Accessed December 10, 2017. And, note the opposite position: Eric Foner, "Birthright Citizenship Is the Good Kind of American Exceptionalism," The Nation, August 15, 2015, at <https://www.thenation.com/ article/birthright-citizenship-is-the-good-kind-of-american-exceptionalism/ $>$. Accessed December 10, 2017. 
controversial decisions, most significantly to Roe v. Wade (1973), establishing the right to an abortion.

4) Obergefell $v$. Hodges (2015), ruling that the fundamental right to marry is guaranteed to same-sex couples by both the Due Process Clause and the Equal Protection Clause of the $14^{\text {th }}$ Amendment. ${ }^{2}$

As of 2016, many conservative Republicans (including Trump) found themselves resistant to some of these progressive court verdicts.

The $14^{\text {th }}$ Amendment's provision regarding citizenship is one of four clauses contained in the Amendment's first paragraph. Although this essay emphasizes the issue of citizenship, that issue is significantly linked to the other clauses in the first paragraph, which include the Privileges or Immunities Clause, the Due Process Clause, and the Equal Protection Clause. The Amendment entered the Constitution in 1868 during what has been described as "Radical Reconstruction."

This consequential legal instrument began as a piece of legislation called the Civil Rights Act of 1866, passed over President Andrew Johnson's veto. However, the majority Republican Congress worried that the recently selfreconstructed former Confederate states, formed in the immediate aftermath of the Civil War, would oppose the statutory law and eventually end it. Thus, the Republicans sought to establish its principles within Constitutional law. The white-dominated southern states were bitterly opposed to the Amendment and, with the exception of Tennessee, refused to ratify it. The Congress, then, rejecting the presidential reconstruction process being carried out by President Andrew Johnson, recast Reconstruction policy to ensure that former black slaves would have political rights in the South and be part of a state's governing structure. The Congress saw the new policy as necessary, moral, and correct, given that the white south had begun establishing "black codes," effectively consigning African Americans to a situa-

2 For details, see relevant sections of William Edward Nelson, Fourteenth Amendment: From Political Principle to Judicial Doctrine (Cambridge: Harvard University Press, 1988), Kurt T. Lash, The Fourteenth Amendment and the Privileges and Immunities of American Citizenship (New York: Cambridge University Press, 2014), and Lawrence Baum, editor, The Supreme Court, $12^{\text {th }}$ ed. (Los Angeles: CQ Press, 2015).

3 For a comprehensive overview of Reconstruction, as well as a brief but incisive explanation of the early history of the $14^{\text {th }}$ Amendment, see Eric Foner, Reconstruction: America's Unfinished Revolution (New York, Harper and Row, 1988); chapter 6 covers the specific history of the $14^{\text {th }}$ Amendment. Although Kurt T. Lash's The Fourteenth concentrates on the Privileges and Immunities Clause, it is (particularly Chapter Three) a useful work for gaining insight into the history of the Amendment. 
tion barely better than slavery, which the Civil War had supposedly ended. Thus, military governments were imposed upon the losing Confederate states, and reentry into the Union was conditioned upon accepting all the Reconstruction Amendments $\left(13^{\text {th }}, 14^{\text {th }}\right.$, and $\left.15^{\text {th }}\right) .{ }^{4}$ It is this precise historical action that has led to the notion of the Amendment's illegitimacy, often held by those who advocate the Confederate "lost cause" mantra. ${ }^{5}$

With all of this in mind, we should recall that the question of citizenship, and the complementary issue of rights, was contested in the early republic. Much of the debate revolved around the subject of slavery. Three competing notions of citizenship and rights gained traction by the first half of the $19^{\text {th }}$ century: one argued for citizenship and rights only for those specifically qualified within a discrete culture (typically an individual state) - and that meant exclusively whites; another urged that "popular sovereignty" (i.e., democratic decision) should determine rights and citizenship. A third insisted on a fully inclusive definition of citizenship. By 1868, the $14^{\text {th }}$ Amendment confirmed the latter view. But, as current affairs show, the debate persists, often mirroring some of the arguments found in the early republic's squabbles.

Many see Abraham Lincoln as crafting the final narrative of the American founding, liberating Thomas Jefferson (or, the memory of Jefferson) from his southern acolytes - represented by John C. Calhoun and his anti-liberty colleagues - and from his Northern sycophants, such as Stephen Douglas (the promoter of "popular sovereignty"). ${ }^{6} \mathrm{Had}$ Lincoln lost the competition with Calhoun and Douglas the United States would have entered the $20^{\text {th }}$ century a hobbled and, in terms of rights, uncertain congeries of states. The victory of nationalism over states' rights, liberty over slavery, and inclusive citizenship over parochialism was a crucial historical development.

John C. Calhoun's theory of "states' rights" stood in opposition to the theory of "natural rights" as enunciated in the Declaration of Independence.

4 I am guided here by Foner, Reconstruction, and two older studies: John Hope Franklin, Reconstruction after the Civil War (Chicago: University of Chicago Press, 1961), and W.E.B. Du Bois, Black Reconstruction in America (New York: Harcourt, Brace, 1935).

5 There is only circumstantial and very inconclusive evidence that Donald Trump may have first heard this negative interpretation from his father, who may have been a member of the Ku Klux Klan when a youth. See Philip Bump, "In 1927, Donald Trump's father was arrested after a Klan riot in Queens," Washington Post, February 29, 2016, at <https://www.washingtonpost.com/news/the-fix/wp/2016/02/28/ in-1927-donald-trumps-father-was-arrested-after-a-klan-riot-in-queens/?utm_term=.7803899893ff $>$. Accessed December 10, 2017.

6 See, for example, Garry Wills, Lincoln at Gettysburg: The Words That Remade America (New York: Simon and Schuster, 1992). 
Lincoln maintained that the Declaration and the Constitution must be consonant with one another, which was impossible as long as slavery existed. ${ }^{7}$ But for Calhoun - who was pro-states' rights, pro-slavery, and a forceful thinker-natural rights theory was absurd. He rejected the social contract philosophy of the $17^{\text {th }}$ and $18^{\text {th }}$ centuries. Human beings were not born in nature with "unalienable rights," but, rather, were born in a particular and distinct culture. There were no equal rights of each with others, but simply practices of a given culture. Thus, Calhoun would say, "it is a great and dangerous error to suppose that all people are equally entitled to liberty. It is a reward to be earned, not a blessing to be gratuitously lavished on all alike."

Citing "the illustrious Jefferson" in his Fort Hill Address of July 26, 1831, Calhoun quoted from the Kentucky Resolves, composed by Jefferson in 1798 and one of the initial states'-rights protests against national power. Calhoun used the Jeffersonian doctrine that states individually had the authority to nullify federal action. He also began his address by insisting on the "great and leading principle" that the United States emanated from "the people of the several States, forming distinct political communities (...) and not from all the people forming one aggregate political community."

The challenge from Stephen Douglas was in some respects more troublesome, for the "little giant" from Illinois emphasized "democracy" as a cure for major disputes within the nation, including the dispute over slavery. For Lincoln and Douglas, embraced in the titanic Illinois Senate campaign of 1858 , the issue was clear: Douglas's "popular sovereignty" doctrine would allow white men to vote, democratically, on whether or not to allow slavery in the new territories. Lincoln, arguing from the principles of the Declaration, insisted that because rights were from nature and "unalienable," not even an overwhelming majority could take them away from any individual.

At the October 7 debate at Galesburg, Illinois, Douglas cited Thomas Jefferson to support popular sovereignty and to defy his opponent.

7 Harry Jaffa, “Jaffa vs. Bork: An Exchange,” The National Review, March 21, 1994, 58.

8 John C. Calhoun, Disquisition on Government and Selections from the Discourse, ed. C. Gordon Post (New York: The Liberal Arts Press, 1953), 3, 42, 45. An excellent study of Calhoun is John Niven, John C. Calhoun and the Price of Union (Baton Rouge: Louisiana State University Press, 1988); for the discussion above, see particularly pages $35,84,188,312-317,332$.

9 Calhoun, "Fort Hill Address, July 26, 1831," in Calhoun to Frederick W. Symmes, July 26, 1831, The Papers of John C. Calhoun, ed. Clyde N. Wilson (Columbia: University of South Carolina Press, 1978), XI, 416, 415. Emphasis added. 
I tell you that in my opinion this (...) doctrine of Mr. Lincoln's declaring that negroes and white men were included alike in the Declaration of Independence, made equal by Divine Providence, is a monstrous heresy. The signers of the Declaration of Independence never dreamed of the negro when they were writing that document. They referred to white men, men of European birth and European descent, when they declared the equality of all men. (...) when Thomas Jefferson wrote that Declaration he was the owner, and continued to the end of his life the owner of a large number of slaves. Did he intend to say that his negro slaves were created his equals by Divine law, and that he was violating the law of God (...) by holding slaves? Bear in mind that when that Declaration was put forth every one of the thirteen Colonies were slaveholding Colonies, and every man who signed the Declaration of Independence represented a slaveholding constituency. Bear in mind that no one of them emancipated his slaves, much less put them in an equality with himself when he signed the Declaration. (...) Now I say to you frankly that in my opinion this Government was made by our fathers on the white basis. It was made by white men for the benefit of white men and their posterity, forever (...) under our Constitution and political system the negro is not a citizen - cannot be a citizen - ought not be a citizen. ${ }^{10}$

\section{Douglas's position of exclusivity based on race is not the same as Calhoun's more elaborate theory, but it is, as was Calhoun's schema, a challenge to any universalist, inclusive claim. Here is how Lincoln responded:}

He [Douglas] has alluded to the Declaration of Independence, and has insisted that negroes are not meant by the term "men" in that Declaration of Independence, and that it is a slander upon the framers of that instrument to suppose that they so meant. He asks you if it is possible to believe that Mr. Jefferson, who penned the Declaration of Independence, would have supposed himself as applying the language to the negro race, and yet have held a portion of that race in slavery, and not at once have freed them! I have only to remark upon this point briefly, for I shall not detain you or myself upon it, that I believe the entire records of the world from the date of the Declaration of Independence up to within three years ago, may be searched in vain for one single declaration from one single man, that the negro was not included in the Declaration of Independence. I think I may defy Douglas to show that he ever said so, Therefore, I think I may defy Douglas to show that any President ever said so - that any member of Congress ever said so-that any man ever said so until the necessities of the Democratic party had to invent that declaration. And I will remind Judge Douglas and this audience, that while Mr. Jefferson was the owner of slaves, as he undoubtedly was, he, speaking on this very subject, used the strong language that he trembled for his country when he remembered that God was just. I will offer the highest premium in my power to Judge Douglas, if he will show that he, in all his life, has ever uttered a sentiment akin to that sentiment of Jefferson's. ${ }^{11}$

10 Debate at Galesburg, October 7, 1858, The Lincoln-Douglas Debates, ed. Harold Holzer (New York: Harper Collins, 1993), 247-248. For biographical information on Douglas, see Martin H. Quitt, Stephen A. Douglas and Antebellum Democracy (New York: Cambridge University Press, 2012). Quitt's book may be juxtaposed with an older biography: Robert Walter Johannsen, Stephen A. Douglas (New York: Oxford University Press, 1973).

11 Lincoln's Reply at Galesburg, October 7, 1858, Holzer, Lincoln-Douglas Debates, 252-253. 
Here was a weighty debate about the meaning of American history. Douglas would win the election. Would Lincoln win the debate?

Lincoln's challengers, represented in the formidable persons of Calhoun and Douglas, had forwarded alluring social and political views, widely accepted not only in their own time, but in later times as well. Calhoun's insistence on protecting a minority against a majority would seem to be the converse of Douglas's popular sovereignty argument, yet it is important to note that both contentions are based on the notion that rights are wholly contingent; in the one case because they derive from a "peculiar" culture or society, in the other case because they derive from majority decision, irrespective of any higher standard. And both are arguments for repression (because both condone slavery).

The geographic expansion of the United States to imperial-like continental reach in the period of Lincoln's gradual political ascendency provides other evidence of differences within America on the issues of citizenship and rights. By the middle of the $19^{\text {th }}$ century there were at least two quite different conceptions of the meaning of that empire, mirroring the debates described just above.

One was represented by John L. O'Sullivan and his confederates and called "Manifest Destiny," and a different view was represented by, among others, William H. Seward, who served as Lincoln's Secretary of State.

"Manifest Destiny" was an avowedly racist pronouncement about the expanding nation. Seward, no less an expansionist than O'Sullivan, foresaw a much more heterogeneous and wide-reaching republic.

O'Sullivan, editor of the popular New York Morning News, and Douglas's political ally, wrote in 1845: "It will come to pass that the confederated democracies of the Anglo-American race will give this great continent as an inheritance to man...the population will be homogeneous. This latter element of power and stability has heretofore been wanting to all great empires." 12

Seward began his career as an anti-slavery Whig from New York, was an early Republican, and gave famous anti-slavery speeches, including his

12 New York Morning News, October 13, 1845; cited in Frederick Merk, Manifest Destiny and Mission in American History (New York: Random House, 1963), 34. Emphasis added. It should be underscored that Stephen Douglas and O'Sullivan shared political views; both were Democrats. For more on O'Sullivan, see Robert D. Sampson, John L. O'Sullivan and His Times (Kent, Ohio: The Kent State University Press, 2003). 
"higher law" and "irrepressible conflict" addresses..$^{13}$ His differences with O'Sullivan's Manifest Destiny are plain in an oration he delivered in 1853, on the occasion of the Dedication of Capital University, in Columbus, Ohio. His topic was "The Destiny of America." 14

\section{Seward spoke of}

the borders of the federal republic which will be extended so that it [the republic] shall greet the sun when he touches the tropic, and when he sends his glancing rays toward the polar circle, and shall include even distant islands in either ocean (...) The expansion shall, however, proceed, guided by a political philosophy which teaches that nations, like individuals, are equal moral, social, responsible persons, existing not for objects of merely selfish advantage and enjoyment, but for the performance of duty, which duty consists in elevating themselves and all mankind as high as possible in knowledge and virtue; that the human race is one in its origin, its rights, its duties, and its destiny.

\section{He condemned}

Those who employ (...) force to perpetuate their power, and they do this most effectually by dividing classes and castes, races and nations, and arraying them for mutual injury or destruction against each other. (...) The example of Rome is often commended to us for our emulation. Let us consider it then with becoming care (...) [E]very nation, however remote, was regarded as an enemy [by Rome,] to be conquered, to be despoiled and enslaved, that Rome might be rich and might occupy the world alone.

Plebeians, prisoners of war, and slaves were "kept asunder by discriminating laws and carefully cherished prejudices. (...) Thus did Rome, while enslaving the world, blindly prepare the machinery for her own overthrow by the agency of domestic factions. (...) The wife [even] was a slave."

How, according to Seward, did this kind of "Roman" empire compare to the United States? Well, he said, the United States has done, and will do, several things differently from past empires; for example, we will establish a system of education that is "equal and universal" and "adapted equally to the education of both the sexes, and of all races." Whereas we started as an homogeneous nation, we now have and will continue to incorporate "large

13 For details on Seward, see Walter Stahr, Seward: Lincoln's Indispensable Man (New York: Simon \& Schuster, 2012).

14 From George E. Baker, ed., The Life of William H. Seward with Selections from his Works (New York: Redfield, 1855), 327-350. Emphases added. 
and various foreign elements in our society." Indeed, in an earlier letter, Seward expressed a different view from O'Sullivan's when writing, "The intermingling of races always was, and always will be, the chief element of civilization." 15

While the customs or oppressions of imperfect humans might at times or in places deprive other humans of their rights - their rights derived from their humanity alone, not their rights granted from distinct cultures, as Calhoun would maintain - such practices were unacceptable, indeed invalid, as bases upon which to erect a modern nation. Whereas in a democracy as promoted by Douglas, justice is in the interest of the majority, which is "stronger," Lincoln insisted (as the late Harry Jaffa pointed out in his celebrated book, Crisis of the House Divided) that "the case for popular government depended upon a standard of right and wrong independent of mere opinion."16

A horrific Civil War ultimately brought resolution to the debate. With the $14^{\text {th }}$ Amendment in 1868 , the nation confirmed Lincoln's and Seward's reading of its history.

This is what the famed first paragraph of that Amendment says, in the lapidary language penned by its framers, after considerable discussion and compromise in the Congress:

All persons born or naturalized in the United States, and subject to the jurisdiction thereof, are citizens of the United States and of the State wherein they reside. No State shall make or enforce any law which shall abridge the privileges or immunities of citizens of the United States; nor shall any State deprive any person of life, liberty, or property, without due process of law; nor deny to any person within its jurisdiction the equal protection of the laws. [Italics and emphases added]

15 Seward to James Maher, March 15, 1844, ibid., 498. Although Seward's sentiments about the expanding country may be more attractive to liberal modern readers than the views of his political adversaries, his conventional sense of Roman history may require modification. Here is what the historian Mary Beard has written: "In its early centuries at least, standard Roman practice, unique in the ancient world and most of the modern, was to turn those it had defeated into Roman citizens and to convert erstwhile enemies into allies and future manpower. It was an empire built...on the extension of citizenship and the incorporation of outsiders." "Why Ancient Rome Matters to the Modern World," The Guardian, 2 October 2015. Found at:

<https:/www.theguardian.com/books/2015/oct/02/mary-beard-why-ancient-rome-matters>. Accessed December 6, 2016.

16 Harry V. Jaffa, Crisis of the House Divided: An Interpretation of the Issues in the Lincoln-Douglas Debates (Chicago: University of Chicago Press, 1982), 3. 
Historian Eric Foner has said of the Amendment, it "changed and broadened the meaning of freedom for all Americans (...) [and] permanently altered American nationality" 17 While there would be (perhaps will be) retreats in the future, by 1868 it appeared as though Lincoln, Seward, and the $14^{\text {th }}$ Amendment had triumphed over the alternative conceptions of the meaning of America.

Still, as seen above in this essay, the Amendment continues to elicit controversy. Sometimes the disputes surrounding it rather remind of the debates of earlier periods in the nation's history. But the Amendment does, then, offer an opportunity for contemplation about the current situation and about the full meaning of American nationality. By establishing the sine qua non of non-exclusive, national citizenship, the $14^{\text {th }}$ Amendment made universal and immanently viable both rights and participation in the polity. The principle of national citizenship and unequivocal rights, irrespective of race, ethnicity, gender/sex, nationality, religion, or any other distinction seemed $-21^{\text {st }}$ century presidential candidates notwithstanding-embedded in America's constitutional DNA. But, as current events reveal, the debate goes on.

\section{Bibliography}

Baker, George E., ed. The Life of William H. Seward with Selections from his Works. New York: Redfield, 1855.

Baum, Lawrence, editor. The Supreme Court, 12th ed. Los Angeles: CQ Press, 2015.

Beard, Mary. "Why Ancient Rome Matters to the Modern World." The Guardian (2 October 2015).

$<$ https://www.theguardian.com/books/2015/oct/02/mary-beard-why-ancient-rome-matters $>$. Accessed December 6, 2016.

Calhoun, John C. Disquisition on Government and Selections from the Discourse. C. Gordon Post, ed. New York: The Liberal Arts Press, 1953.

Du Bois, W.E.B. Black Reconstruction in America. New York: Harcourt, Brace, 1935.

Foner, Eric. Reconstruction: America's Unfinished Revolution. New York: Harper and Row, 1988.

Franklin, John Hope. Reconstruction after the Civil War. Chicago: University of Chicago Press, 1961.

Gass, Nick. "Trump to O'Reilly: 14th Amendment is unconstitutional." POLITICO (August 8, 2015).

$<$ http://www.politico.com/story/2015/08/donald-trump-bill-oreilly-interview-121515>. Accessed December 6, 2016.

Holzer, Harold, ed. The Lincoln-Douglas Debates. New York: Harper Collins, 1993. 
Jaffa, Harry V. Crisis of the House Divided: an Interpretation of the Issues in the LincolnDouglas Debates. Chicago: University of Chicago Press, 1982. "Jaffa vs. Bork: An Exchange." The National Review (March 21, 1994), 58.

Johannsen, Robert Walter. Stephen Douglas. New York: Oxford University Press, 1973.

Lash, Kurt T. The Fourteenth Amendment and the Privileges and Immunities of American Citizenship. New York: Cambridge University Press, 2014.

Merk, Frederick. Manifest Destiny and Mission in American History. New York: Random House, 1963.

Nelson, William Edward. Fourteenth Amendment: From Political Principle to Judicial Doctrine. Cambridge: Harvard University Press, 1988.

Niven, John. John C. Calhoun and the Price of Union. Baton Rouge: Louisiana State University Press, 1988.

Quitt, Martin H. Stephen A. Douglas and Antebellum Democracy. New York: Cambridge University Press, 2012.

Sampson, Robert D. John L. O'Sullivan and His Times. Kent, Ohio: The Kent State University Press, 2003.

Stahr, Walter. Seward: Lincoln's Indispensable Man. New York: Simon \& Schuster, 2012.

Wills, Garry. Lincoln at Gettysburg: The Words That Remade America. New York: Simon and Schuster, 1992.

Wilson, Clyde N., ed. The Papers of John C. Calhoun . Columbia: University of South Carolina Press, 1978. 